\title{
Influence of suspended mussel lines on sediment erosion and resuspension in Lagune de la Grande Entrée, Îles-de-la- Madeleine, Québec, Canada
}

\author{
Walker Tony R. ${ }^{1,{ }^{*}}$, Grant Jon ${ }^{1}$, Weise Andréa M. ${ }^{2}$, Mckindsey Christopher W. ${ }^{2,}{ }^{3}$, Callier Myriam ${ }^{2,3,4}$, \\ Richard Marion ${ }^{2,3,5}$
}

\footnotetext{
${ }^{1}$ Dalhousie University, Department of Oceanography, Halifax, NS, Canada

${ }^{2}$ Fisheries and Oceans Canada, Maurice Lamontagne Institute, Environmental Sciences Division, 850 route de la mer, Mont Joli, QC, Canada

${ }^{3}$ Institute des Sciences de la Mer, Université du Quebec à Rimouski, 310 allée des Ursulines, Rimouski, QC, Canada

${ }^{4}$ Institut Français de Recherche pour l'Exploitation de la Mer (IFREMER), Centre Méditerranée, Département des Ressources Biologiques et Environnement, Laboratoire Aquaculture Languedoc Roussillon, UMR 5119 ECOSYM, Chemin de Maguelone, Station de Palavas, 34250 Palavas-les-Flots, France

${ }^{5}$ Institut Français de Recherche pour l'Exploitation de la Mer (IFREMER), Département Océanographie et Dynamique des Ecosystèmes, Laboratoire Environnement Ressources du Languedoc Roussillon, Station de Sète - Avenue Jean Monnet, 34203 Sète, Cedex, France
}

*Corresponding author : Tony R. Walker, email address : tonyrobertwalker@gmail.com

\begin{abstract}
:
Downward fluxes of organically rich biodeposits under suspended mussel lines can cause benthic impacts such as changes in benthic community structure or microbial mat production. Quantifying sediment erosion in these coastal ecosystems is important for understanding how fluxes of organic matter and mussel biodeposits contribute to benthic-pelagic coupling. Critical shear velocity ( $\mathrm{u}^{*} \mathrm{crit}$ ), erosion rates and particle size distributions of resuspended sediment were measured at four stations distributed along a transect perpendicular to a mussel farm in Lagune de la Grande Entrée, Îles-de-laMadeleine (Quebec, Canada). Stations were selected underneath the outer-most mussel line $(0 \mathrm{~m})$ and at distances of $15,30 \mathrm{~m}$ and at a reference station $(500 \mathrm{~m})$ further along the transect. Shear velocity was measured using a calibrated portable Particle Erosion Simulator, also referred to as the BEAST (Benthic Environmental Assessment Sediment Tool). Undisturbed sediment cores obtained by divers were exposed to shear stress to compare differences between stations. Erosion sequences indicated no significant differences in $\mathrm{u}^{*}$ crit between stations, but there were significant differences in erosion rates beneath mussel lines compared to other stations. Erosion rates were the highest in cores from beneath mussel lines, but paradoxically had the lowest $u^{*}$ crit. Mean erosion rates at $u^{*}$ crit varied between 25 and
\end{abstract}


$47 \mathrm{~g} \mathrm{~m}^{-2} \mathrm{~min}^{-1}$ and critical erosion thresholds varied between 1.58 and $1.73 \mathrm{~cm} \mathrm{~s}^{-1}$, which compare with intensive mussel culture sites elsewhere in eastern Canada. Significant differences existed in biotic and abiotic properties of sediments which could explain variation in maximum erosion rates within and between stations. Particle sizes measured by videography of resuspended sediment at different shear velocities ranged from 0.2 to $3.0 \mathrm{~mm}$. Quantifying sediment erosion from intact marine sediments helps to improve our mechanistic understanding of these processes, and the BEAST further contributes to predictive capability in benthic-pelagic coupling modeling.

\section{Highlights}

- An erosion device was used to quantify sediment near cultured mussels. Erosion rates were significantly higher beneath mussel lines. Critical shear velocities compared to other studies in eastern Canada The BEAST contributes to our understanding of benthic-pelagic coupling.

Keywords : Sediment erosion, Shear velocity, Resuspension, Biodeposits, Particle size, Mytilus edulis

\section{Introduction}

Quantification of sediment erosion around coastal aquaculture operations is essential for understanding fluxes of organic rich particu1ate matter. Sedimentation, sinking rates and dispersion of organic and inorganic partic1es (comprising of phytoplankton, sediment, detritus, fecal pellets or resuspended aggregates), is dependent on particle diameter and density, and are highly variable in coastal water colurnns (Andersen et al., 2002; Miller et al., 2002; Nickell et al., 2003; Giles and Pilditch, 2004). Sedimentation is further compounded by filter-feeding bivalves which play an important role in coastal ecosystems through their influence on benthic-pelagic coupling and nutrient cycling (Christensen et al., 2003). Filter-feeding bivalves repackage fine suspended material into larger organic rich biodeposits (feces and pseudofeces) that sink more rapidly than their constituents, increasing fluxes of organic matter to the benthos, depending on water depth, currents and resuspension (Chamberlain et al., 2001). While dynamics of mussel biodeposition (resuspension and disaggregation) is poorly quantified, enhanced sedimentation under mussel culture is well documented (e.g., Hatcher et al., 1994; Callier et al., 2006). 
69 Bottom sediment resuspension is affected by biostabilization, porosity, organic

70 content, grain size, and bioturbation (Miller et al., 2002; Nickell et al., 2003; Giles and

71 Pilditch, 2004; Walker and Grant, 2009). Quantifying sediment resuspension is important

72 for understanding sediment erosion thresholds (critical shear velocity, $u_{*}{ }_{\text {crit }}$ ) and fluxes

73 generated by currents or waves becomes an important predictive tool in coastal

74 ecosystem management. Quantifying sediment transport is possible when erosion

75 thresholds are known, although few calibrated data exist for sediment entrainment rates

76 (Tolhurst et al., 2000; Grant et al., 2013), especially those influenced by mussel

77 biodeposits or microbial mats (Walker and Grant, 2009). Sediment stability (defined as

78 increased erosion threshold) is often associated with biostabilizing microbial mats,

79 including diatoms and/or bacteria which can physically bind cohesive and non-cohesive

80 sediment particles via the excretion of extracellular polymeric substances (Grant et al.,

81 1986; Grant and Gust, 1987; Tolhurst et al., 2002). Alternatively, bioturbation can

82 destabilize sediments by increasing porosity or by grazing on stabilizing organisms

83 (Gerdol and Hughes, 1994). Sediment erosion thresholds are therefore difficult to predict,

84 due to varying biotic and abiotic influences. Moreover, erosion thresholds are difficult to

85 measure for undisturbed sediments, requiring substantial effort using laboratory or field

86 flume quantification (Widdows et al., 1998).

87 Downward fluxes of organic biodeposits under suspended mussel culture operations

88 has been reported to have local adverse benthic impacts, decreasing biodiversity and

89 increasing sulfate reduction leading to anaerobic conditions (see review by McKindsey et

90 al., 2011). Whilst some modeling studies have considered erosion and dispersion around

91 mussel aquaculture sites (Giles et al., 2009; Wiese et al., 2009), combined field 
92 measurements of sediment erosion rates from suspension-feeding bivalves has rarely

93 been investigated (Widdows et al., 1998; Miller et al., 2002; Giles and Pilditch, 2004;

94 Walker and Grant, 2009). Recent studies associated with mussel aquaculture in Lagune

95 de la Grande Entrée (LGE) have documented benthic impacts associated with

96 biodeposition, including nutrient and particle fluxes (Callier et al., 2006, 2009; Richard et

97 al., 2006, 2007a, 2007b). Ecosystem models of aquaculture carrying capacity on the

98 basis of mussel grazing have also beeen conducted there (Grant et al., 2007; Filgueira et

99 al., 2012). However, the fate of biodeposits through dispersion and resuspension events

100 remains unclear in LGE (Callier et al., 2006; Weise et al., 2009). This is especially

101 important if benthic microalgae are resuspended as an additional mussel food source

102 (Frechette and Grant, 1991).

103 We re-designed and calibrated a portable erosion chamber called the 'Benthic

104 Erosion Assessment Sediment Tool' (BEAST) (Grant et al., 2013) to measure erosion in

105 undisturbed sediment cores in an attempt to field verify biodeposit dispersion model

106 predictions in LGE. The following objectives were undertaken: (1) quantify erosion

107 thresholds, erosion rates, and resuspended particle size distributions along a SW transect

108 perpendicular to a mussel line in the direction of main current flow; (2) determine

109 sediment organic quality; and (3) compare erosion features to a separate study by Callier

110 et al. (2006) who measured downward fluxes of biodeposits and spatial extent of

111 dispersion investigated via sediment traps located along the same transect.

112

\section{2. Methods}

114 2.1. Study site 
115 This study was conducted below and adjacent to a mussel farm in LGE, îles-de-la-

116 Madeleine, Quebec, in August 2004. Îles-de-la-Madeleine are in the Gulf of St. Lawrence

117 in eastern Canada, with LGE $\left(58 \mathrm{~km}^{2}\right)$ located in the northeast of the largest island ( $47^{\circ}$

$\left.11837^{\prime} \mathrm{N}, 61^{\circ} 31^{\prime} \mathrm{W}\right)$. Mean currents are weak $\left(<5 \mathrm{~cm} \mathrm{~s}^{-1}\right)$ occasionally increasing to $10 \mathrm{~cm}$

$119 \mathrm{~s}^{-1}$ during strong wind events, resulting in a well-mixed water column (Koutitonsky et al., 120 2002). A deep navigation channel (8 m) separates LGE into a shallow (1-3 m) sandy area

121 to the west and a deeper (5-7 m) muddy basin to the east where the mussel farm is located

122 (Fig. 1). Blue mussels, Mytilus edulis L. are cultured using longlines with continuous

123 socking looping between floats and the farm has operated since the 1980 s, currently

124 producing $180 \mathrm{t} \mathrm{yr}^{-1}$ in a farm area of $2.5 \mathrm{~km}^{2}$ (Weise et al., 2009).

125

126 2.3. Sediment sampling stations

127 Triplicate intact sediment samples were collected in Plexiglas ${ }^{\mathrm{TM}}$ cores $(11.2 \mathrm{~cm}$ I.D.) by

128 SCUBA divers for erosion experiments and particle size distribution from stations along

129 a SW transect perpendicular to a mussel line along the direction of main current flow

130 (i.e., underneath a mussel line to a reference station). Sampling stations were located 0 ,

$131 \quad 15$ and $30 \mathrm{~m}$ from the mussel line. A reference station was selected at a sandy site located

$132500 \mathrm{~m}$ further along the transect (Fig. 1). Three additional sediment cores were collected

133 from each station for determination of sediment physical properties, using sub-cores over

134 the $0-1 \mathrm{~cm}$ depth horizon with truncated $5 \mathrm{~mL}$ plastic syringes for measurement of grain

135 size, percent organic matter (\%OM), percent total organic carbon (\%TOC) and C:N

136 ratios. 


\section{2.4. Sediment properties}

139 Sub-samples were stored at $-20 \mathrm{C}$ in pre-weighed plastic scintillation vials until analysis.

140 Triplicate thawed samples were wet sieved with tap water through 63-2000 $\mu \mathrm{m}$ sieves.

141 Sub-samples of $<63 \mu \mathrm{m}$ suspended sediment were collected and filtered through GF/F

142 filters for analysis of \%OM. For \%OM, filter residues and sediments were oven dried at

$14360^{\circ} \mathrm{C}$ for $3 \mathrm{~d}$ to constant weight, followed by ashing in a furnace oven at $520^{\circ} \mathrm{C}$ for $24 \mathrm{~h}$

144 before re-weighing. Sediment texture distribution was determined using GRADISTAT

145 (Blott and Pye, 2001). Sediments were ananlyzed for C:N ratios using a CHN elemental

146 analyzer (Perkin-Elmer 2400) (Walker, 2005).

$148 \quad 2.5$. Sediment erosion thresholds and erosion rates

149 Sediment erosion thresholds and erosion rates were determined on triplicate cores from

150 each station using the BEAST with methods that have been reported elsewhere in greater

151 detail (Walker et al., 2008; Walker and Grant, 2009; Grant et al., 2013). Briefly, cores

152 were filled with approximately $1 \mathrm{~L}$ of seawater overlying a $30 \mathrm{~cm}$ sediment column and

153 stored in a dark water bath $\left(10^{\circ} \mathrm{C}\right)$ to equilibrate before erosion was performed. The

154 plunger disc was inserted into the core liner, and oscillation imposed for $2 \mathrm{~min}$. intervals

155 at equivalent shear velocities of $0.9-2.6 \mathrm{~cm} \mathrm{~s}^{-1}$. Onset of sediment erosion was detected

156 via turbidity and digital imaging. Initial particle movement is detected as erosion of flocs,

157 while the sediment surface remains intact. Critical shear velocity is defined as a more

158 generalized failure of the bed. We have used these categories previously (Grant et al.,

159 2013), finding them to be more applicable to our BEAST erosion sequences than the

160 Type I and II terms classically used (Tolhurst et al., 2000). 
161 Turbidity in erosion chamber was monitored using \% transmission as a proxy for

162 sediment concentration with an in situ fiber-optic spectrophotometer (Brinkmann PC 800

163 colorimeter, $670 \mathrm{~nm}$ ). The fiber-optic probe was zeroed with filtered seawater and

164 calibrated using thawed frozen sediment samples covering a range of concentrations from

165 all stations. Sediment slurries were filtered through GF/F to determine suspended

166 particulate matter (SPM) concentrations.

167 Sequences of sediment erosion and erosion activity at the sediment bed were

168 recorded visually using a mini-DV camcorder (Canon ZR45 MC) and analyzed following

169 protocols from our previous studies (Walker et al., 2008). Digital still images were

170 obtained at $1 \mathrm{~min}$. intervals using video capture software (Pinnacle Studio version 8,

171 Pinnacle systems). Particle size analysis of images was determined with SigmaScan Pro

172 version 5 (SPSS Inc.) image analysis software. Particles could only be discriminated at

173 lower shear velocities before SPM concentrations became too turbid. Minimum particle

174 sizes measured using estimated spherical diameter (ESD) was $200 \mu \mathrm{m}$.

175 Erosion rates were calculated according to Walker and Grant (2009). The

176 spectrophotometer gave linear responses to SPM concentrations of sandy sediments at all

177 stations covering concentrations from $0-7700 \mathrm{mg} \mathrm{L}^{-1}$, so that each $\%$ transmission unit

178 represented a specific SPM concentration. Erosion rates were calculated for each time

179 interval based on this linear relationship with respect to sediment core surface area (98

$\left.180 \mathrm{~cm}^{2}\right)$.

181

182

\subsection{Statistical analysis}


183 Significant differences were determined using Minitab to perform one-way analysis of

184 variance (ANOVA) followed by Tukey's test at the $P<0.05$ level (unless indicated

185 otherwise).

186

187 3. Results

188 1.1.Sediment properties

189 Sediment grain size composition and significance tests for \%TOC, \%OM and C:N ratios

190 are shown in Fig. 2. Sediments were comprised of silty sand at $0 \mathrm{~m}$ or fine sand at

191 remaining stations. Median grain sizes $\left(D_{50}\right)$ at $0 \mathrm{~m}$ were $90 \mu \mathrm{m}$, with similar slightly

192 coarser sizes at 15 and $30 \mathrm{~m}$, increasing to $180 \mu \mathrm{m}$ at $500 \mathrm{~m}$. Percent TOC and $\% O M$

193 varied between stations with lowest values measured at $500 \mathrm{~m}$. This was expected of the

194 coarser sediment found in the far field. However, the $0 \mathrm{~m}$ farm sediments were finest, yet

195 lower in \%OC them the more distant farm sites. The 15 and $30 \mathrm{~m}$ sediments were not

196 significantly different in organic or carbon content. Sediment C:N ratios were 7-8 at 15,

19730 , and $500 \mathrm{~m}$, but significantly higher at $0 \mathrm{~m}$ with a values of 12 . This may reflect more

198 degraded sedimentary organic material arising from mussel feces.

199

200 3.2. Erosion experiments

201 Observations of erosion sequences show consistent behaviour of the three variables (Fig.

202 3). Shear stress is applied in consistent linear manner. Turbidity remains constant or

203 diplays a slow increase as flocs are resuspended until the initiation of more general

204 erosion, and then shows a steep increase (declining \% transmission). Erosion rate

205 provides an instantaneous measure of sediment dynamics that remains at a low level until 
206 the onset of general erosion when it displays a marked increase. The shapes of these

207 curves are used to distinguish important differences between stations. Specifically,

208 turbidity curves in cores from beneath mussel lines, experienced sharp transitions to

209 erosion once protective organic rich carpets were disrupted at this station (Fig. 3). This

210 was in contrast to other stations, where transitions to erosion were more gradual,

211 probably due to larger grain sizes and the absence of mats. Critical shear velocity ( $\mathrm{u}^{*}$ crit)

212 was reached between $1.58-1.73 \mathrm{~cm} \mathrm{~s}^{-1}$ at all stations. Mean erosion rates at $u^{*}$ crit varied

213 between $25-47 \mathrm{~g} \mathrm{~m}^{-2} \mathrm{~min}^{-1}$ at $30 \mathrm{~m}$ and $0 \mathrm{~m}$, respectively.

215 The behaviour of both turbidity and erosion rate are variable in the chamber experiments,

216 and few consistent differences between stations can be observed. In some cases, an

217 increase in turbidity occurred well before the general erosion threshold, indicating that

218 the accumulation of surface flocs accounts for sunstantial resuspension. As expected, the

219 onset of general erosion occurs at the peak of erosion rate, and afer a rapid increase in

220 this rate. The only consistent spatial difference is that in cores from the mussel farm,

221 initial floc movement began at a lower speed than at reference sites. Otherwise, metrics

222 such as the erosion threshold and the erosion rate at this threshold are variable enough to

223 obscure spatial differences.

224 Cores from $0 \mathrm{~m}$ appeared to have a shallow light brown oxidized layer which

225 penetrated $<1.5 \mathrm{~cm}$, although according to Callier et al. (2008) these sediments were

226 largely anoxic up to a depth of $10 \mathrm{~cm}$ below the surface. Before onset of erosion the

227 water column remained clear, but with increasing shear stress, larger particles $(>0.4 \mathrm{~mm})$

228 began lifting. The first phase of erosion was observed when turbidity began to increase at 
$2291.40 \mathrm{~cm} \mathrm{~s}^{-1}$. As further stress was applied, the bed failed and the second phase of erosion 230 was observed $\left(\mathrm{u}^{*}\right.$ crit $\left.=1.58 \mathrm{~cm} \mathrm{~s}^{-1}\right)$, with the suspension becoming fully turbid. Shear

231 stress at $u_{*}$ crit was sufficient to lift larger particles (upto $2 \mathrm{~mm}$ ) and maintain them in 232 suspension.

233 Cores from $15 \mathrm{~m}$ contained deeper light brown surface layers between $0.5-2 \mathrm{~cm}$.

234 The second phase of erosion, occurred at $u_{\text {crit }}$ of $1.73 \mathrm{~cm} \mathrm{~s}^{-1}$ and shear stress was

235 sufficient to lift particles between $0.2-1 \mathrm{~mm}$. Cores from 30 and $500 \mathrm{~m}$ stations contained

236 a shallow light brown surface layer between $0.6-1 \mathrm{~cm}$ deep and the second phase of

237 erosion occurred at $\mathrm{u}_{*}$ crit of $1.67 \mathrm{~cm} \mathrm{~s}^{-1}$ and $1.72 \mathrm{~cm} \mathrm{~s}^{-1}$, respectively with particles

238 between $0.2-3 \mathrm{~mm}$.

239 Decreasing \% transmission values had tight linear relationships with SPM

240 concentration measured by filtration and gravimetry $\left(R^{2}=0.93-0.99\right)$, corresponding to

241 mean SPM concentrations of between 2931 to $7763 \mathrm{mg} \mathrm{L}^{-1}$ (Fig. 4a). Mean erosion rates

242 were recorded up to $47 \pm 2.9 \mathrm{~g} \mathrm{~m}^{-2} \mathrm{~min}^{-1}$ at $0 \mathrm{~m}$ and only $25 \pm 2.5 \mathrm{~g} \mathrm{~m}^{-2} \mathrm{~min}^{-1}$ at $30 \mathrm{~m}$ from

243 the mussel line and were significantly different $(P<0.01)$ (Fig. 4b). There were no

244 obvious relationships between critical shear stress and erosion rates across stations $\left(\mathrm{R}^{2}=\right.$

245 0.29) (Fig. 4c). Frequency of resuspended particle sizes, with increasing shear velocity,

246 ranged from 0.1-3.0 mm for all stations and for all erosion thresholds (Fig. 5). Image

247 analysis of particles sizes became difficult $>\mathrm{u}^{*}$ of $1.7 \mathrm{~cm} \mathrm{~s}^{-1}$, due to increasing turbidity.

248 Particles $<200 \mu \mathrm{m}$ were below levels of detection for this method and are not shown.

249 Overall, there appears to be subtle differences in particle size distributions across stations, 250 with more particles resuspended at lower shear velocities at $0 \mathrm{~m}$ compared to $500 \mathrm{~m}$. 


\section{Discussion}

253 One of the primary impacts of mussel culture is enhanced biodeposition of fecal and

254 pseudofecal material (Cranford et al., 2009). Many studies have documented

255 environmental effects due to this increased sedimentation including impacts associated

256 with eutrophication, e.g., sediment hypoxia, increased sulfate reduction, and greater

257 effluxes of ammonium (Danovaro et al., 2004; Hartstein and Rowden, 2004; Callier et al., 258 2007, 2008; Richard et al., 2007a, 2007b; McKindsey et al., 2011). Among the resultant

259 biotic responses to organic loading are the development of microbial mats, and decline in

260 benthic invertebrate biodiversity due to their sensitivity to sulfide concentrations (Pearson

261 and Rosenburg, 1978; Hatcher et al., 1994; Chamberlain et al., 2001).

262 Several studies have shown that increasing biodeposition from bivalve culture

263 may lead to changes in sediment composition, resulting in muddy, anaerobic sediments

264 (e.g., Hatcher et al., 1994). In our study, the finest sediment was found at the mussel

265 lines, mirroring size fractions reported by Callier et al. $(2006,2008)$. Sediment at the

266 longlines also had the highest $\mathrm{C}: \mathrm{N}$ suggesting that the biodeposits are degraded from

267 grazing and digestion. Callier et al. (2008) did not report any significant difference

268 between other sediment characteristics (including \%OM) or benthic communities along

269 the same transect. Taken together these studies and the present work suggest that the

270 LGE farm had little effect on the local environment. The lack of localized impacts in

271 LGE was perhaps influenced by wind induced resuspension in this shallow water site

272 (Koutitonsky et al., 2002).

273 Critical erosion thresholds of sediments at all stations occurred when shear

274 velocities reached between $1.58-1.73 \mathrm{~cm} \mathrm{~s}^{-1}$, which compare favorably with field 
275 measurements made at intensive mussel culture sites in Prince Edward Island, Canada

276 (Walker and Grant, 2009). Analysis of sediment erosion sequences indicated there were

277 no significant differences in sediment $\mathrm{u}^{*}$ crit between stations and there was as much inter-

278 as intra-station variation, although the limited replicates used in this study probably

279 highlighted the relatively high intra-station variation. More studies using additional cores

280 to perform erosion sequences would likely decrease the intra-treatment variability of our

281 erosion thresholds and may potentially highlight significant differences along the

282 transect. There were however significantly higher erosion rates beneath mussel lines (47

$283 \mathrm{~g} \mathrm{~m}^{-2} \mathrm{~min}^{-1}$ ), where fluxes of organic matter to sediments were high due to increased

284 biodeposition, compared to $30 \mathrm{~m}\left(25 \mathrm{~g} \mathrm{~m}^{-2} \mathrm{~min}^{-1}\right)$. A simple explanation is that there is

285 similar fine material in a background of sand at each site. This produces a similar

286 threshold for erosion based on a visual criterion or change in turbidity. However, the

287 erosion rate is greater at the longlines, because there is more of the fine material available

288 to erode. If shear velocity is estimated as $5 \%$ of free stream (Gordon et al., 2004), then

289 even the higher range of currents measured in the vicinity of the farm are below critical

290 shear velocity.

291 Our erosion sequences clearly show two phases of erosion, an initial phase

292 (surficial) and a second phase (critical erosion). According to Tolhurst et al. (2000)

293 cohesive sediments erode in several phases, as a function of depth of the eroded layer.

294 We demarcated the distinction between phases of erosion on the basis of surficial layer

295 events, where the first phase of erosion (i.e., flocs, biofilms, surface mm of sediment) was

296 compared to the second phase of erosion (i.e., failure of sediment surface to $\mathrm{cm}$-scale

297 depths and a sharp increase in turbidity) (Grant et al., 2013). 
Initially, in all cores, except for those collected beneath mussel lines $(0 \mathrm{~m})$, there

299 was little or no change in turbidity, with only a few small particles eroding from the

300 surface (first phase of erosion). However as turbidity began to increase, erosion rates

301 increased dramatically until a second phase of erosion was achieved whereby further

302 increases in shear stress did not appear to increase erosion rates. Although sediment

303 concentration and particle size maybe difficult to correlate at high shear velocities (due to

304 poor visibility in cores), they are both dependant on turbulent shear (Walker et al., 2008).

305 At low shear velocities in erosion sequences using sediment cores collected from beneath

306 suspended mussel lines it appeared that larger aggregates were resuspended first (Fig. 5).

307 For example, in our recent studies on microbial mats, sediments which were initially

308 biostabilized against erosion due to an 'armoring' effect, the onset of erosion was abrupt

309 once these mats failed, resulting in the resuspension of large mat fragments (Walker and

310 Grant, 2009).

311 Much of the feces biodeposition, from mussel culture may have become

312 incorporated into these sediments and the method used here for sediment grain size

313 analysis may have resulted in the destruction of these bio-aggregates. This may have

314 underestimated the binding effects of the microbial mats and may therefore, not correlate

315 well with sediment erodibility, particularly for sediments beneath mussel lines which had

316 the highest erosion rates. Studies by Fugate and Friedrichs (2003) noted that biological

317 aggregations initially resisted turbulent breakup in sediment erosion studies in

318 Chesapeake Bay, but Paterson (1989), found that sediments underlying biofilms (once

319 exposed), were more easily eroded than the biostabilized layer itself. A similar response

320 in sediment stability was observed by Walker and Grant (2009) around mussel culture 
321 sites in Tracadie Bay, where mean erosion thresholds of $1.74 \mathrm{~cm} \mathrm{~s}^{-1}$ and erosion rates of

$32247 \mathrm{~g} \mathrm{~m}^{-2} \mathrm{~min}^{-1}$ were recorded. These results compare favorably with erosion rates and

323 thresholds reported in this study, as erosion experiments on cores containing large areas

324 of eelgrass, Zostera marina initially resisted erosion, but when turbulent breakup did

325 occur, large fragments above the sediment bed were observed.

326 Erosion rate calculations respond to small changes in turbidity at each time step

327 and are a sensitive indicator of instantaneous resuspension. As the first phase of erosion

328 began, a steep rise in erosion rate was observed. With increased stress, more scouring of

329 unconsolidated material occured and during the second phase of erosion, the rate began to

330 decrease as the bed eroded to more consolodated sediments yielding fewer and larger

331 particles. These observations reiterate previous studies which demonstrate that there are

332 multiple erosion thresholds, dependent on sediment texture and the vertical distribution of

333 shear strength (Tolhurst et al., 2000).

334 Erosion rates around mussel culture sites in this study were higher than those

335 reported by Giles and Pilditch (2004), that found organic rich biodeposits from mussels

336 were easily eroded at thresholds $<1 \mathrm{~cm} \mathrm{~s}^{-1}$. Again, this was probably due in part to

337 biostabilization of microbial mats, the presence of eelgrass and the textural properties of

338 sediments beneath mussel lines in LGE. Normally in natural sediments fecal material

339 reduces sediment stability (Andersen et al., 2002), but in this study biodeposits probably

340 contributed to microbial mat biomass.

341 Several physical and biological properties of the sediment surface were measured

342 in order to determine a suitable quantitative predictor of the erodibility of sediment (e.g., 343 grain size, \%OM content, \% $\mathrm{TOC}$ and $\mathrm{C}: \mathrm{N}$ ratios). There were also other contributions to 
344 organic enrichment in LGE, such as the presence of large amounts of detritus (e.g.,

345 eelgrass) and microbial mats revealed from diver observations and evidenced in several

346 core samples. The accumulation of fine particles in the sediment at these sites may be

347 influenced by limited tidal exchange, removal of biodeposits by feeding mussels during

348 wind-induced resuspension events, and subsequent biostabilization of the fine fraction at

349 the sediment-water interface by microbial mats, and the construction of a navigation

350 channel in the 1980 's which probably changed the hydrodynamics of the lagoon. The

351 physical characteristics of the sediments at these stations, and others along the transect in

352 LGE have previously been described by (Callier et al., 2006, 2007), who reported no

353 difference in sediment \%OM between 0 and $15 \mathrm{~m}$ from the mussel line. Also they found

354 no difference in the depth of the sediment oxic layer between 0 and $15 \mathrm{~m}$ from mussel

355 line, where sediments were reduced and blackened with a sulfide layer, however, the 30

$356 \mathrm{~m}$ station was more oxidized. There was also no difference in abundance of infauna, wet

357 weight biomass and diversity of species between the three stations at 0,15 and $30 \mathrm{~m}$

358 (Callier et al., 2007).

359 Callier et al. (2006) reported that measured deposition of mussel biodeposits were

360 fairly localized along the transect in LGE, albeit with some inter-annual variation, and

361 was in broad agreement with modeled biodeposit settling rates by Weise et al. (2009).

362 However negative benthic impacts were more diffuse along the same transect. The

363 amount of organic enrichment along the transect in this study was fairly uniform except

364 at the reference station, which may partly explain the lack of significant differences

365 observed in erosion sequences between stations. However, the amount of \%TOC and

$366 \% \mathrm{OM}$ was highest at $30 \mathrm{~m}$ from the mussel line, suggesting that dispersal via the 
367 dominant current flow direction (with current velocities sometimes exceeding $\mathrm{u}^{*}{ }_{\text {crit }}$ values

368 measured here), was responsible for transporting material. The lowest erosion thresholds

369 (but highest erosion rates), were recorded directly below the mussel line, where the

370 increased deposition of organically rich biodeposits may have already caused changes in

371 the sediment textural properties but not the benthic community structure (Callier et al.,

372 2006). This contrasts to the increases in grain size observed further along the transect,

373 where slightly higher erosion thresholds were observed.

374 Our work in modeling the role of resuspension in benthic-pelagic coupling is

375 limited by accurate estimates of erosion characteristics, whose prediction is often mired

376 in complex biophysical interactions (Grant et al., 2013; Walker et al., 2008). This is

377 particularly true of erosion studies with microbial mats where armoring is so important to

378 the erosion process close to mussel aquaculture sites (Walker and Grant, 2009). The use

379 of the BEAST as a proxy for quantifying sediment erosion demonstrates its practical

380 capability to provide quantitative field measurements of transport parameters from

381 undisturbed marine sediments to improve our mechanistic understanding of these

382 processes, and further contributes to predictive capability in modeling of benthic-pelagic

383 coupling. Future applications using this device could include environmental effects

384 monitoring to improve habitat and ecosystem management of potential changes in

385 benthic ecosystems near coastal aquaculture operations. More studies are required in

386 order to fully understand the effects of sediment erosion and resuspension from the

387 impacts of biodeposition from mussel aquaculture in these shallow coastal sites.

388

389 Acknowledgements 
390 We thank MAPAQ and B. Hargrave for collaboration and C. Éloquin and associates for

391 permission to use their site. Funding was provided by Aquaculture Collaborative

392 Research and Development Program (ACRDP), Société de Dévelopment de l'Industrie

393 Maricole (SODIM) and Fisheries and Oceans Canada. We thank B. Schofield and M.

394 Merrimen for fabrication of the BEAST which formed part of the equipment necessary

395 for the Canadian Arctic Shelves Exchange Study (CASES), a Research Network funded

396 by the Natural Sciences and Engineering Research Council of Canada (NSERC).

398 References

399 Andersen, T.J., Jensen, K.T., Lund-Hansen, L., Mouritsen, K.N., Pejrup, M., 2002.

400 Enhanced erodibility of fine-grained marine sediments by Hydrobia ulvae. J. Sea Res. 48, $401 \quad 51-58$.

402 Blott, S.J., Pye, K., 2001. GRADISTAT: A grain size distribution and statistics package

403 for the analysis of unconsolidated sediments. Earth Surf. Process Landforms 26, 1237-

4041248.

405 Callier, M.D., Weise, A.M., McKindsey, C.W., Desrosiers, G., 2006. Sedimentation rates

406 in a suspended mussel farm (Great-Entry Lagoon, Canada): biodeposit production and

407 dispersion. Mar. Ecol. Prog. Ser. 322, 129-141.

408 Callier, M.D., McKindsey, C.W., Desrosiers, G., 2007. Multi-scale spatial variations in

409 benthic sediment geochemistry and macrofaunal communities under a suspended mussel

410 culture. Mar. Ecol. Prog. Ser. 348, 103-115. 
411 Callier, M.D., McKindsey, C.W., Desrosiers, G., 2008. Evaluation of indicators used to

412 detect mussel farm influence on the benthos: two case studies in the Magdalen Islands,

413 Eastern Canada. Aquaculture 278, 77-88.

414 Callier, M.D., Richard, M., McKindsey, C.W., Archambault, P., Desrosiers, G., 2009.

415 Responses of benthic macrofauna and biogeochemical fluxes to various levels of mussel

416 biodeposition: an in situ "benthocosm" experiment. Mar. Pollut. Bull. 58, 1544-1553.

417 Chamberlain, J., Fernandes, T.F., Read, P., Nickell, T.D., Davies, I.M., 2001. Impacts of

418 deposits from suspended mussel (Mytilus edulis L.) culture on the surrounding surficial

419 sediments. ICES J. Mar. Sci. 58, 411-416.

420 Christensen, P.B., Glud, R.N., Dalsgaard, T., Gillespie, P., 2003. Impacts of longline

421 mussel farming on oxygen and nitrogen dynamics and biological communities of coastal

422 sediments. Aquaculture 218, 567-588.

423 Cranford, P., Hargrave, B.T., Doucette, L.I., 2009. Benthic organic enrichment from

424 suspended mussel (Mytilus edulis) culture in Prince Edward Island, Canada. Aquaculture $425 \quad 292,189-196$.

426 Danovaro, R., Gambi, C., Luna, G.M., Mirto, S., 2004. Sustainable impact of mussel

427 farming in the Adriatic Sea (Mediterranean Sea): evidence from biochemical, microbial

428 and meiofuanal indicators. Mar. Pollut. Bull. 49, 325-333.

429 Filgueira, R., Grant, J., Bacher, C., Carreau, M., 2012. A physical-biogeochemical

430 coupling scheme for modeling marine coastal ecosystems. Ecologic. Inform. 7, 71-80.

431 Frechette, M., Grant, J., 1991. An in situ estimation of the effect of wind-driven

432 resuspension on the growth of the mussel Mytilus edulis L. J. Exp. Mar. Biol. Ecol. 148, $433 \quad 201-213$. 
434 Fugate, D.C., Friedrichs, C.T., 2003. Controls on suspended aggregate size in partially

435 mixed estuaries. Estuar. Coast. Shelf. Sci. 58, 389-404.

436 Gerdol, V., Hughes, R.G., 1994. Effect of Corophium volutator on the abundance of

437 benthic diatoms, bacteria and sediment stability in two estuaries in southeastern England.

438 Mar. Ecol. Prog. Ser. 114, 109-115.

439 Giles, H., Pilditch, C.A., 2004. Effects of diet on sinking rates and erosion thresholds of

440 mussel Perna canaliculus biodeposits. Mar. Ecol. Prog. Ser. 282, 205-219.

441 Giles, H, Broekhuizen, N., Byran, K.R., Pilditch, C.A., 2009. Modelling the dispersal of

442 biodeposits from mussel farms: The importance of simulating biodeposit erosion and

443 decay. Aquaculture 291, 168-178.

444 Gordon, N.D, McMahon, T.A., Finlayson, B.L, Gippel, C.J., Nathan, R.J., 2004. Stream

445 Hydrology: An Introduction for Ecologists. John Wiley and Sons, NJ. 254 p.

446 Grant, J., Gust, G., 1987. Prediction of coastal sediment stability from photopigment

447 content of mats of purple sulphur bacteria. Nature 330, 244-246.

448 Grant, J., Bathmann, U.V., Mills, E.L., 1986. The interaction between benthic diatom

449 films and sediment transport. Estuar. Coast. Shelf. Sci. 23, 225-238.

450 Grant, J., Walker, T.R., Hill, P.S., Lintern, D.G., 2013. BEAST-A portable device for

451 quantification of erosion in intact sediment cores. Meth Oceanog. 5, 39-55.

452 Grant, J., Curran, K.J., Guyondet, T.L., Tita, G., Bacher, C., Koutitonsky, V., 2007. A

453 box model of carrying capacity for suspended mussel aquaculture in Lagune de la

454 Grande-Entrée, Iles-de-la-Madeleine, Québec. Ecol. Mod. 200, 193-206.

455 Hartstein, N.D., Rowden, A.A., 2004. Effect of biodeposits from mussel culture on

456 macroinvertebrate assemblages at sites of different hydrodynamic regime. Mar. Environ. 
457 Res. 57, 339-357.

458 Hatcher, A., Grant, J., Schofield, B., 1994. Effects of suspended mussel culture (Mytilus

459 spp.) on sedimentation, benthic respiration and sediment nutrient dynamics in a coastal

460 bay. Mar. Ecol. Prog. Ser. 115, 219-235.

461 Koutitonsky, V.G., Navarro, N., Booth, D., 2002. Descriptive physical oceanography of

462 Great-Entry Lagoon, Gulf of St. Lawrence. Estuar. Coastal Shelf Sci. 54, 833-847.

463 McKindsey, C.W., Archambault, P., Callier, M.D., Olivier, F., 2011. Influence of

464 suspended and off-bottom mussel culture on the sea bottom and benthic habitats: a

465 review. Can. J. Zool. 89, 622-646.

466 Miller, D.C., Norkko, A., Pilditch, C.A., 2002. Influence of diet on dispersal of horse

467 mussel Atrina zelandica biodeposits. Mar. Ecol. Prog. Ser. 242, 153-167.

468 Nickell, L.A., Black, K.D., Hughes, D.J., Overnell, J., Brand, T., Nickell, T.D., Breuer,

469 E., Harvey, S.M., 2003. Bioturbation, sediment fluxes and benthic community

470 structure around a salmon cage farm in Loch Creran, Scotland. J. Exp. Mar. Biol. Ecol.

$471 \quad 285-286,221-233$.

472 Paterson, D.M., 1989. Short-term changes in the erodibility of intertidal cohesive

473 sediments related to the migratory behavior of epipelic diatoms. Limnol. Oceanog. 34,

$474 \quad 223-234$.

475 Pearson, T.H., Rosenburg, R., 1978. Macrobenthic succession in relation to organic

476 enrichment and pollution of the marine environment. Oceanog. Mar. Biol. Ann. Rev. 16, $477 \quad 229-311$. 
478 Richard, M., Archambault, P., Thouzeau, G., Desrosiers, G., 2006. Influence of

479 suspended mussel lines on the biogeochemical fluxes in adjacent water in the Îles-de-la-

480 Madeleine (Quebec, Canada). Can. J. Fish. Aquat. Sci. 63, 1198-1213.

481 Richard, M., Archambault, P., Thouzeau, G., Desrosiers, G., 2007a. Summer influence of

482 1- and 2-yr-old mussel cultures on benthic fluxes in Grande-Entrée lagoon, îles-de-la-

483 Madeleine (Québec, Canada). Mar. Ecol. Prog. Ser. 338, 131-143.

484 Richard, M., Archambault, P., Thouzeau, G., McKindsey, C.W., Desrosiers, G., 2007b.

485 Influence of suspended scallop cages and mussel lines on pelagic and benthic

486 biogeochemical fluxes in Havre-aux-Maisons lagoon, Îles-de-la-Madeleine (Quebec,

487 Canada). Can. J. Fish. Aquat. Sci. 64, 1491-1505.

488 Tolhurst, T.J., Black, K.S., Paterson, D.M., Mitchener, H.J., Termaat, G.R., Shayler, SA.,

489 2000. A comparison and measurement standardization of four in situ devices for

490 determining the erosion shear stress of intertidal sediments. Con. Shelf Res. 20, 1397-

4911418.

492 Tolhurst, T.J., Gust, G, Paterson, D.M., 2002. The influence of an extracellular polymeric

493 substance (EPS) on cohesive sediment stability. In: Winterwerp, J.C. Kranenburg, C.

494 (Eds.), Fine Sediment Dynamics in the Marine Environment. Elsevier Science,

495 Amsterdam. pp. 409-425

496 Walker, T.R., 2005. Vertical organic inputs and bioavailability of carbon in an Antarctic

497 coastal sediment. Polish Pol. Res. 26, 91-106.

498 Walker, T.R., Grant, J., 2009. Quantifying erosion rates and stability of bottom sediments

499 at mussel aquaculture sites in Prince Edward Island, Canada. J. Mar. Syst. 75, 46-55. 
500 Walker, T.R., Grant, J., Cranford, P., Lintern, D.G., Hill, P.S., Jarvis, P., Barrel, J., 501 Nozais, C., 2008. Suspended sediment and erosion dynamics in Kugmallit Bay and

502 Beaufort Sea during ice-free conditions. J. Mar. Syst. 74, 794-809.

503 Weise, A.M., Cromey, C.J., Callier, M.D., Archambault, P., Chamberlain, J., McKindsey, 504 C.W., 2009. Shellfish-DEPOMOD: Modelling the biodeposition from suspended shellish 505 aquaculture and assessing benthic effects. Aquaculture 288, 239-253.

506 Widdows, J., Brinsley, M.D., Bowley, N., Barrett, C., 1998. A benthic annular flume for

507 in situ measurement of suspension feeding/biodeposition rates and erosion potential of 508 intertidal cohesive sediments. Estuar. Coast. Shelf. Sci. 46, 27-38. 


\section{Figure legends}

Fig. 1. Mussel farm (grey rectangles) in Lagune de la Grande Entrée (LGE), îles-de-laMadeleine, Canada. Sampling stations distributed along a SW transect aligned with major current flow 0,15 and $30 \mathrm{~m}$ from mussel farm. A reference station was located $500 \mathrm{~m}$ further along the transect.

Fig. 2. Sediment properties at LGE stations: (a) \%TOC; (b) Proportion of mean sediment grain sizes. Silt and sand are sub-divided into very fine (vf), fine (f), medium (m), coarse (c), and very coarse (vc) fractions. $\mathrm{D}_{50}$ values $(\mu \mathrm{m})$ are indicated; (c) $\% \mathrm{OM}$ determined from a sub-sample of $<63 \mu \mathrm{m}$ SPM collected and filtered through GF/F filters; (d) C:N ratios from $0-1 \mathrm{~cm}$ sediment horizon. Significant differences determined by one-way ANOVA followed by Tukey's test; within each measured attribute, stations with same letters were not significantly different and stations with different letters were significantly different $(P<0.05)$. Plotted values are means \pm SE $(n=3)$.

Fig. 3. Erosion sequences showing shear velocity (o), turbidity (\% transmission) $(\bullet)$ and erosion rate (grey circles) performed on sediment cores using the BEAST at increasing distances from a mussel line: (a) $0 \mathrm{~m}$; (b) $15 \mathrm{~m}$; (c) $30 \mathrm{~m}$ and (d) $500 \mathrm{~m}$. Onset of erosion is indicated by vertical solid line (i.e., turbidity begins to increase). Onset of significant erosion (i.e., critical shear velocity) is indicated by the vertical dashed line which distinguishes between different phases of erosion.

Fig. 4. SPM concentrations at lowest $\%$ transmission (a); peak erosion rate (b); shear velocity at critical shear stress $\left(u_{*} *_{\text {crit }}\right)$ (i.e., second phase of erosion) (c). Significant differences were determined by one-way ANOVA followed by Tukey's test; within each measured attribute, sites with same letters were not significantly different and sites with 
different letters were significantly different $(P<0.05$ for SPM concentrations) and $(P<0.10$ for erosion rate and shear velocity). Plotted values are means \pm S.E. $(n=3)$.

Fig. 5. Frequency of particle sizes (ESD, mm) resuspended from sediment cores under different erosion thresholds. Sampling stations: $0,15,30$ and $500 \mathrm{~m}$ subjected to $\mathrm{u}^{*}$ between, $0.90-1.79 \mathrm{~cm} \mathrm{~s}^{-1}$. Total number $(n)$ of particles assessed at a given shear velocity is indicated above each histogram. 
Fig. 1.

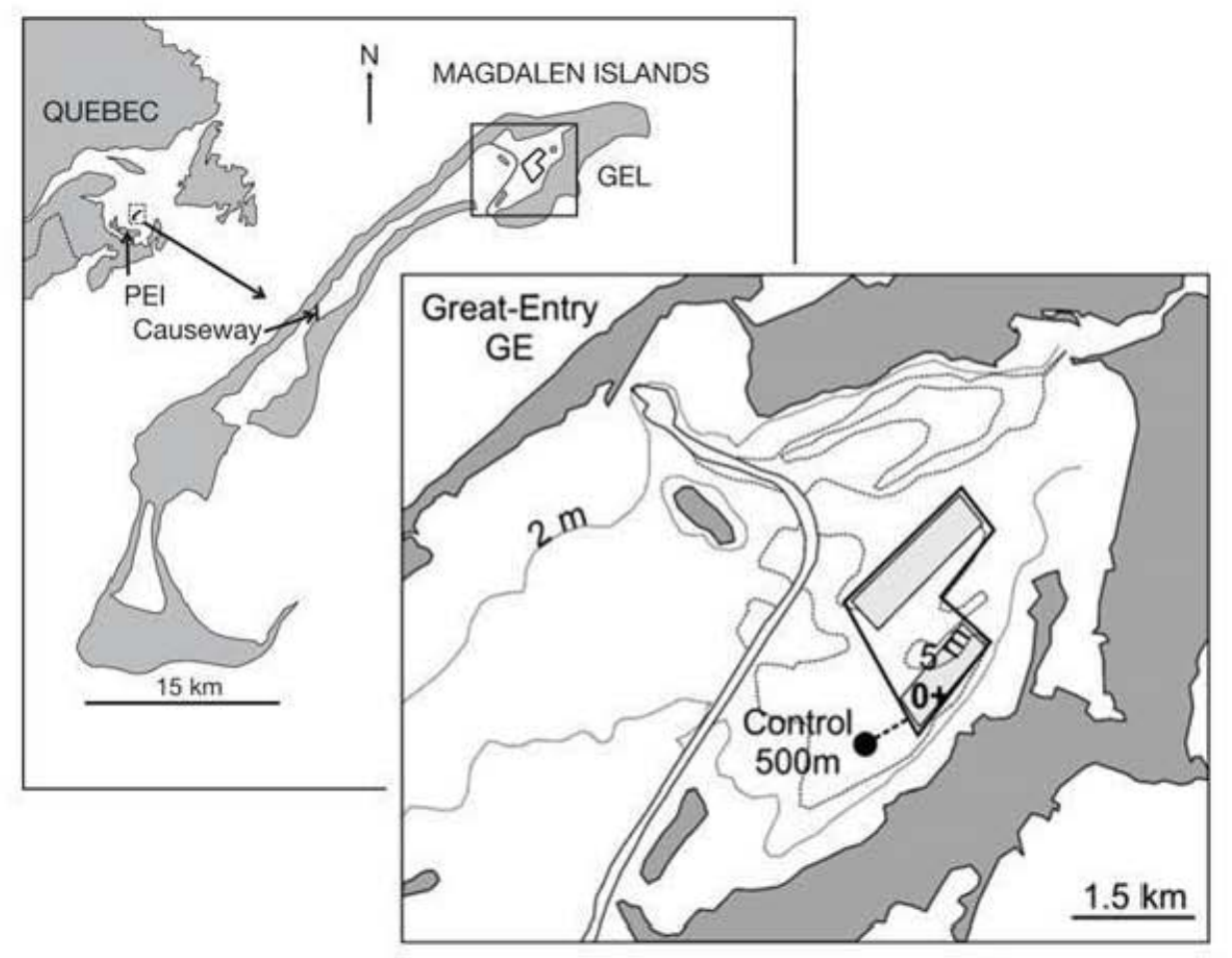

30

31

32 
2

Fig. 2.

(a)

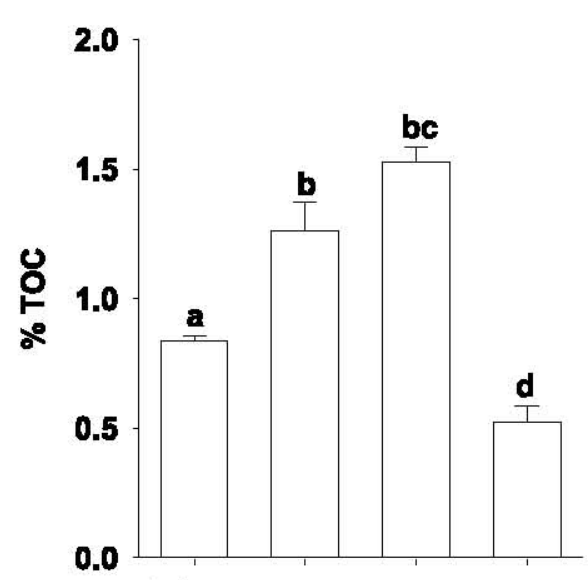

(c)

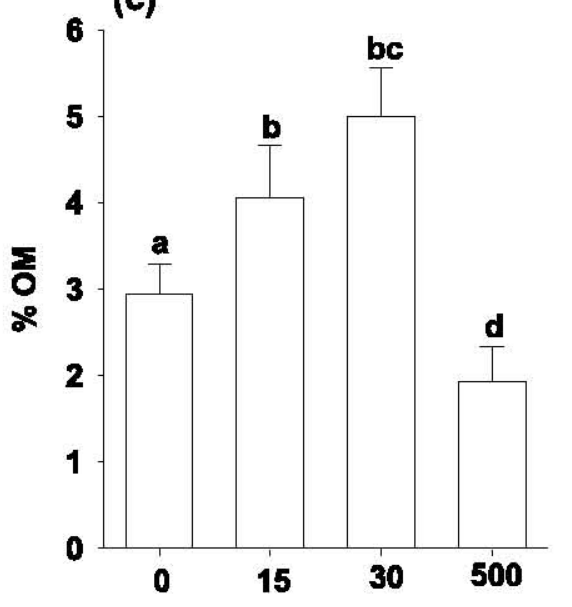

(b)

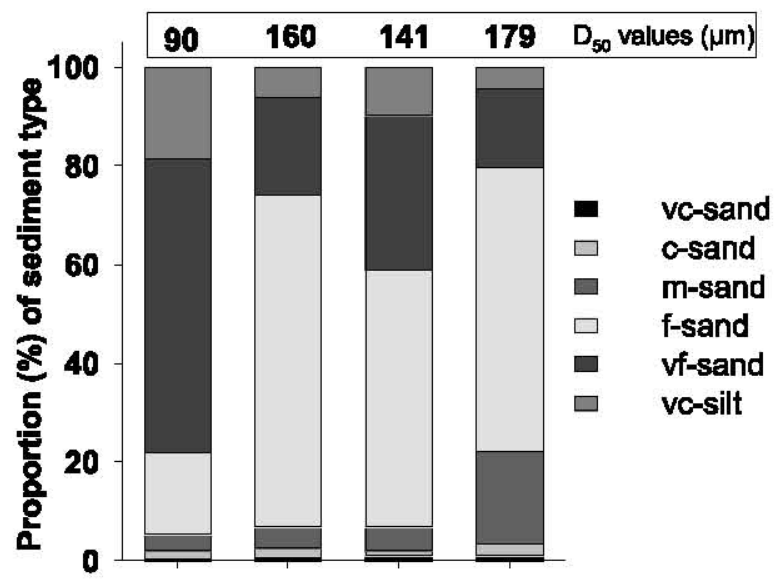

(d)

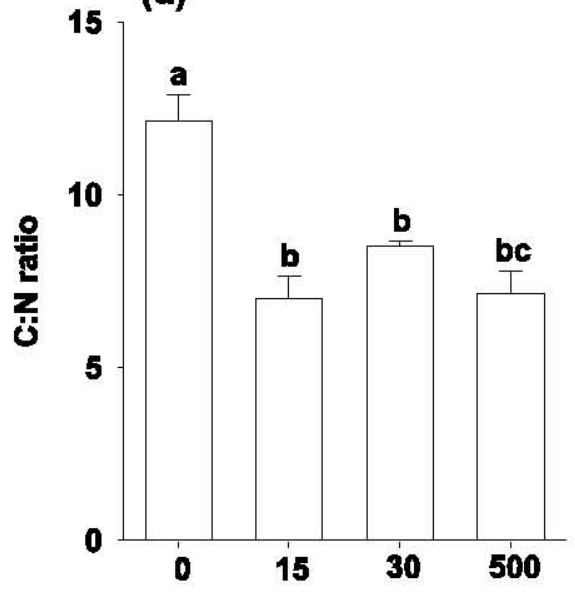

Station distance from farm (m) 
Fig. 3.

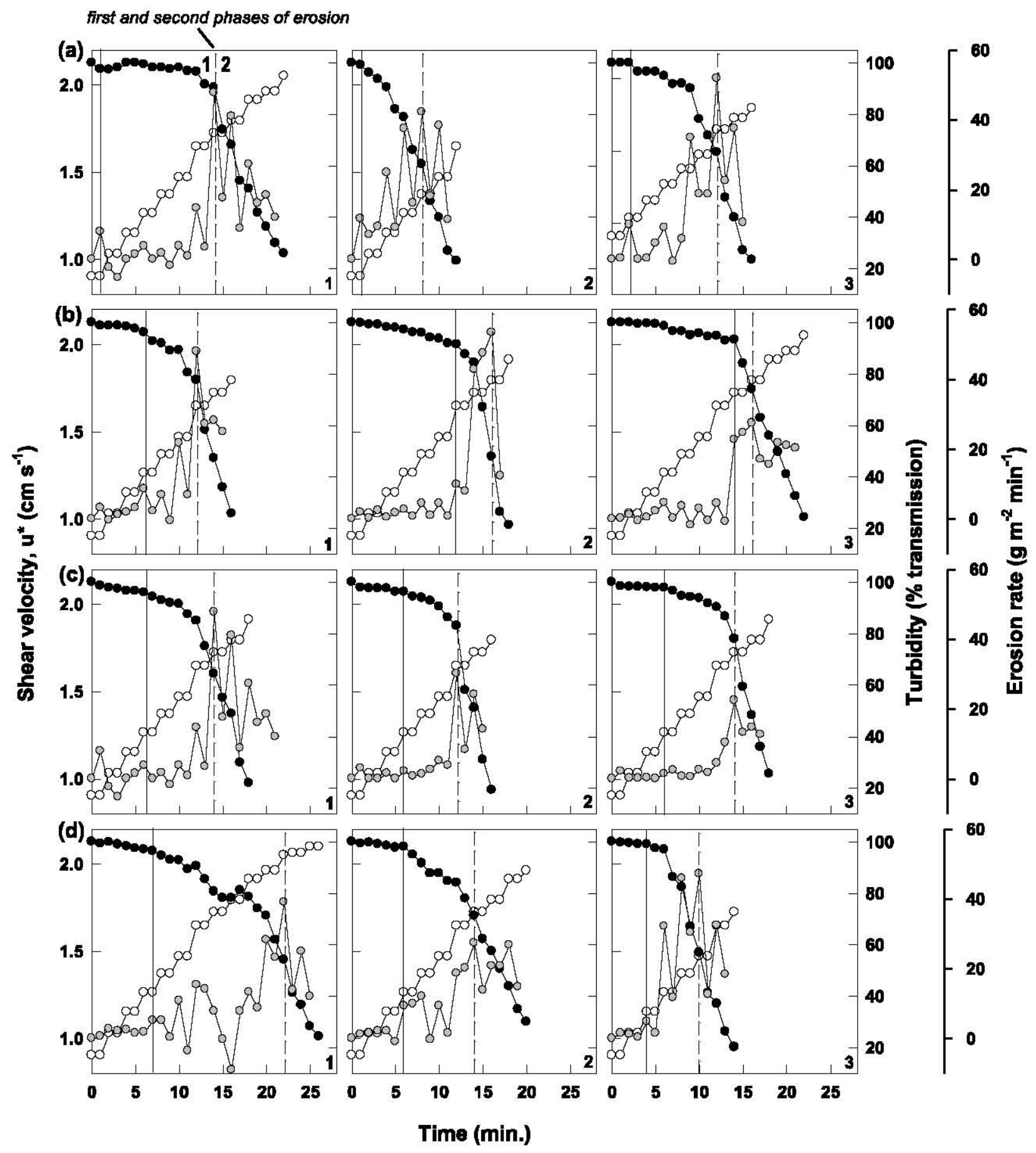


Fig. 4.

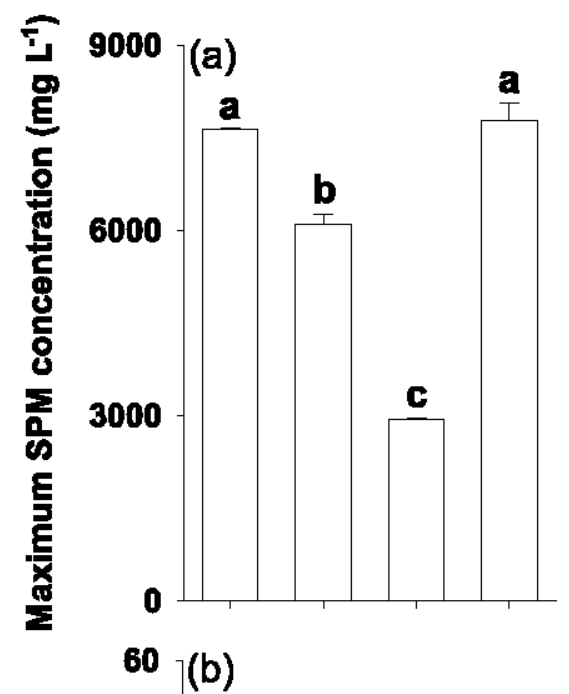

25

26
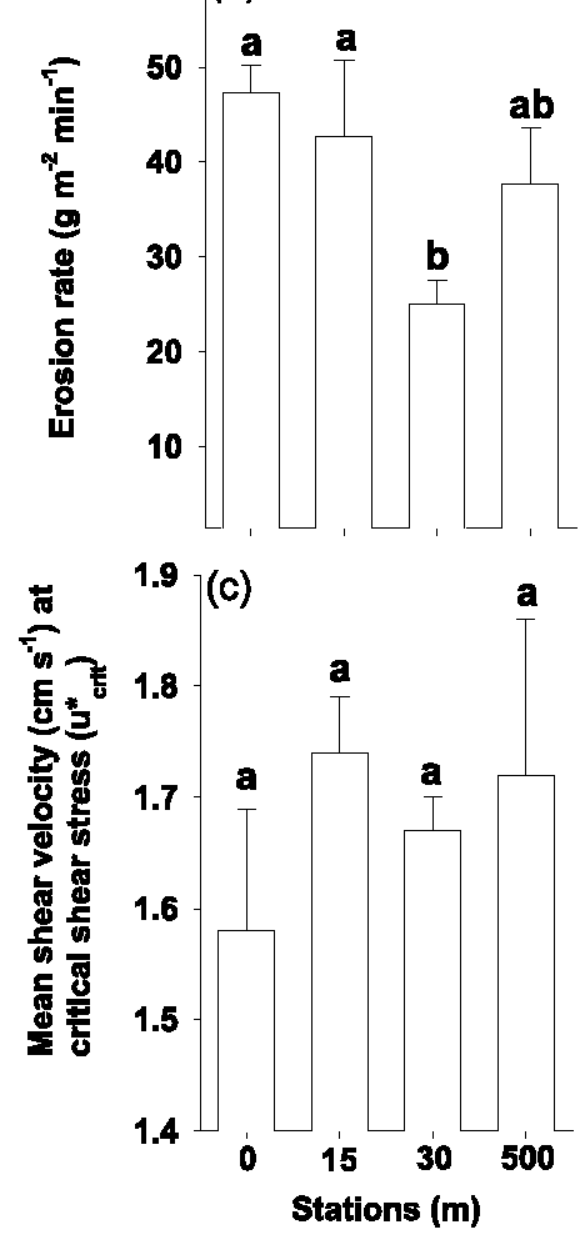
Fig. 5.

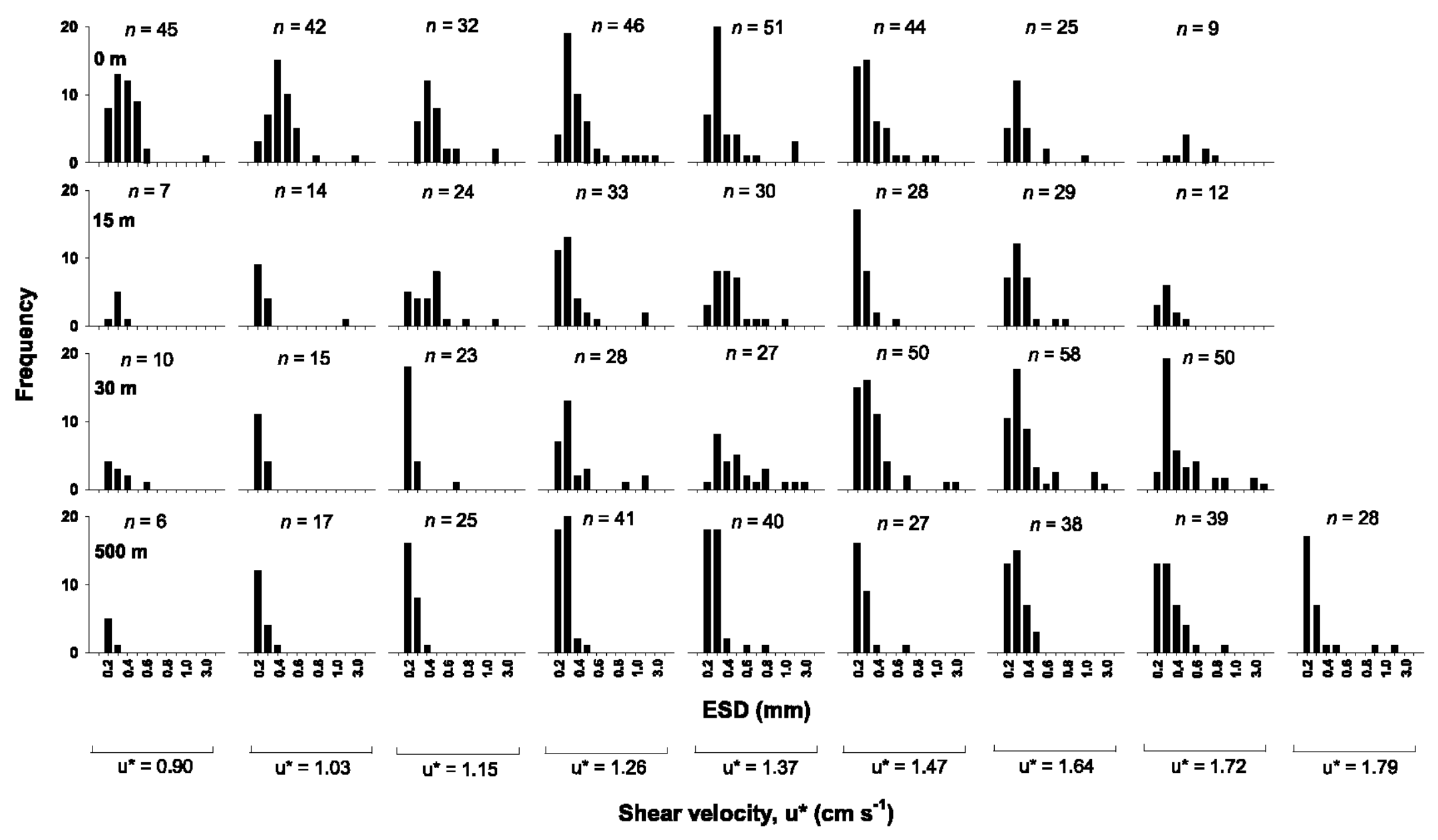

